\title{
EXTENDED THEORY OF PLANNED BEHAVIOR AS MODEL OF ANABOLIC ANDROGENIC STEROID USE BY INDONESIAN BODYBUILDERS
}

\author{
Shine Pintor Siolemba Patiro \\ STMIK AKAKOM Yogyakarta \\ (batikpakuan@gmail.com) \\ Basu Swastha Dharmmesta \\ Faculty of Economics and Business \\ Universitas Gadjah Mada \\ (dharmmesta@ugm.ac.id) \\ Sahid Susilo Nugroho \\ Faculty of Economics and Business \\ Universitas Gadjah Mada \\ (sahid@ugm.ac.id) \\ Bayu Sutikno \\ Faculty of Economics and Business \\ Universitas Gadjah Mada \\ (bayusutikno@ugm.ac.id)
}

\begin{abstract}
This correlational study explored the psychological antecedents of Indonesian bodybuilders' intentions to use anabolic-androgenic steroids (AAS), based on the Theory of Planned Behavior (TPB). The purpose of this research was to identify factors that influence an Indonesian bodybuilder's intention to use AAS and offer a better understanding of AAS use behavior based on the extended Theory of Planned Behavior (TPB). The three predictor variables of (1) attitude, (2) subjective norms, and (3) perceived behavioral control accounted for the variation in the outcome measure of the intention to reuse the AAS. Likewise, (1) attitude and (2) intention accounted for of the variation in the outcome measure of the reuse of AAS. This research combined two methods which are qualitative and quantitative. The respondents who were used in this research are professional bodybuilders located in Jakarta, Bandung, Surabaya, and Yogyakarta. The result of this research shows that the attitude of bodybuilders in using AAS tends to have values that are adopted by themselves. The result of this research differs from Bagozzi et al (1989) who stated that attitude influenced behavior directly as a nonpurposeful reaction or indirectly through intention as an aimed response. The result of this research clearly shows that attitude can influence behavior directly as a purposeful reaction, because the bodybuilders consume AAS to achieve a particular purpose and it is strengthened by achievement value in themselves. This research suggests also that attitude and subjective norms are not causally independent. They appear to reflect similar beliefs and to influence each other. These results differ from Titah and Barki (2009), as suggested by Chang (1998) and Aarts et al. (1998), who stated that a person whose positive subjective norms move them toward overt behavior, it will lead to a positive attitude toward the behavior. Future research directions are suggested regarding several areas.
\end{abstract}

Keywords: theory of planned behavior; values; steroid; bodybuilders 


\section{INTRODUCTION}

One type of doping that is often used by bodybuilders is called Anabolic Androgenic Steroid (AAS). It is a synthetic version of a testosteron hormone (Mitic \& Radovanovic, 2011). AAS is commonly associated with the sport of bodybuilding. The use of AAS is not a new issue for the sport, and the collective term steroid is officially used to denote illegitimate performance enhancement substances and methods among professional and amateur bodybuilders. AAS is mostly taken by athletes and adolescents to enhance performance and physical appearance (Tahtamouni et al., 2008; Amsterdam et al., 2010). The AAS are synthetic substances related to the male sex hormones which influence the growth of skeletal muscles and the development of male sexual characteristics (Lundholm et al., 2010). Skarberg et al. (2009) reported that the use of the AAS was historically limited to professional sports and bodybuilding. However, recent data suggest that steroids have been used by individuals, especially young people who are not involved in sports, but who take the AAS for lifestyle purposes (Simon et al., 2006).

Kompas daily newspaper, Monday, May 6, 2013, reported that the usage rate of AAS had increased across Indonesia. Moreover, it is said that the usage of steroids is not only found among bodybuilders who want to gain an advantage, but also among the public whose lifestyle purpose involves using doping substances. AAS violates sports ethics and may have serious implications for the physical and mental health of the bodybuilders, including cardiovascular conditions, renal complications, rhabdomyolysis, infectious complications from the injection technique used in self administration, tendon and ligament ruptures, thyroidal impairment, azoospermia, major mood disturbances and even increased premature mortality (Amsterdam et al., 2010; Tahtamouni et al., 2008).

The existing literature on the etiology of AAS use is limited and relatively new (Wiefferink et al., 2008). They noted that AAS use in bodybuilding sports is deliberate and planned, and, among other factors, they highlighted the importance of pro-steroid attitudes in predicting steroid use. Indeed, among the few studies on the psychological correlates of steorid use, attitudes appear as significant correlates of steroid behavior in both nonathletes and professional athletes (Anshel \& Russell, 1997; Alaranta et al., 2006; Petroczi et al., 2008). Other studies on non-professional athletes encompassed attitudes and additional variables as proxy measures of steroid behavior. Specifically, Lucidi et al. (2004) and Lucidi et al. (2008) proposed the Theory of Planned Behavior, and showed that the TPB variables (i.e., attitudes, subjective norms, and perceived behavioral control) significantly predicted steroid intentions and behavior.

The TBP has been widely applied in the health behavior domain to predict substance use and a range of other health risk behaviors, and has been found to be superior in comparison with other health behavior models (Armitage \& Conner, 2000). The effectiveness of TPB variables in predicting steroid use intentions were provided in a study with gym users (e.g.,bodybuilders and people practicing fitness sports; Wiefferink et al., 2008). The aforementioned studies suggest that the TPB and/or related behavioral models can be effectively applied in research investigating the use of AAS. However, relevant research on professional or elite athletes is still lacking, especially in Indonesia. Thus there is a gap in our knowledge regarding the influences on AAS use in more advanced levels of bodybuiding sports.

To better understand why AAS use behavior occurs and what influences an Indonesian bodybuilder's intent to use, researchers should determine what factors affect the intention to use, as well as the AAS behavior itself. To this end, the purpose of this research is to identify factors that influence an Indonesian bodybuilders intention to use AAS and offer a better understanding of AAS use behavior based on the extended of Theory of Planned Behavior (TPB)

\section{THEORY AND RESEARCH HYPOTHESIS}

TPB is designed to predict and explain human behavior in specific contexts (Ajzen \& 
Madden, 1986; Ajzen, 1991). Based on the TPB, intention is the best predictor of a behavior, which is, in turn, regulated by attitude toward behavior and related to social normative perceptions along with perceived control over behavior performance (Schifter \& Ajzen, 1985; Ajzen \& Madden, 1986; Ajzen, 1991). According to this theory, attitudes toward the behavior refer to the degree to which one is in favor of, or opposed to, personally performing the behavior; is my performance of the behavior good or bad? Is it harmful or beneficial, pleasant or unpleasant? Subjective norms refer to a person's perception of the degree to which significant others think he or she should or should not perform the behavior. The perceived behavioral control component measures a person's belief that they do or do not have the ability to perform a particular behavior; that performing the behavior is, or is not, under the person's control.

Armitage and Conner (2000) stated that several quantitative and narrative reviews have provided support for use of the TRA and TPB in the prediction of a range of behaviors (e.g., Ajzen, 1991; Sheppard et al., 1988), and health behaviors in particular (e.g., Conner \& Sparks, 1996; Godin \& Kok, 1996; Hausenblas et al., 1997). Godin and Kok (1996) reported a metaanalysis of 87 TPB studies applied to health behavior. Their analyses showed that the TPB accounted for 41 percent of the variance in behavioral intentions $(\mathrm{R}=0.64,76$ correlations) and 34 percent of the variance in behaviors $(\mathrm{R}=0.58,35$ correlations) for a range of health behaviors.

TPB has been effectively applied to understanding and modifying a wide range of health behaviors, and explains, on average, approximately 40 percent of the variance in health related behavioral intentions (Rutter \& Quine, 2002). Additionally, Montano and Kasprzyk (2008) suggested that the TPB provides a systematic framework to determine those important issues that influence a person's decisions to accomplish particular behavior such as intentional use of AAS with a special purpose in mind. In relation to the use of the AAS, the TPB presumes that cognitions such as attitude and social norm may predict the intention to begin using the drug. Various beliefs have been developed around steroid users that influence the attitude towards these products. Each of the various beliefs is supported below as a potential influencer of attitude, subjective norms, and perceived behavioral control towards steroid use.

There are published studies which support the predictive validity of the TPB with respect to the use of AAS. Those are MacKinnon et al. (2001) and Petroczi (2007). Their research framework was based on the TPB and Social Cognitive Theory, which describes behavior as a function of intention, and intention, in turn, as a function of attitudes, social influences and self efficacy. There are also studies which support the notion that the athletes' and adolescents' attitudes are responsible for the deviant behavior of doping (Petroczi, 2007; Goulet et al., 2010). Lucidi et al. (2004) exploited the TPB to provide a theoretical framework for a study among Italian adolescents in which attitude was found to be the strongest predictor for behavioral intention to use doping substances. In addition, published research affirms that subjective norms are one of the TPB constructs that play a seemingly important role in complying with the behavior (Donovan et al., 2002; Strelan \& Boeckmann, 2003; Petroczi, 2007).

On the other hand, researchers have also found that attitude can influence behavior directly, or indirectly, through the intention (Bentler \& Speckart,1979, 1981). Liska et al. (1984) stated that the relationship between attitude and behavior remains a perennial problem in social science. Since the 1960 's, various research has appeared that discusses the influence of attitude on behavior (Fishbein \& Ajzen, 1975; Schuman \& Johnson, 1976; Albrecht \& Carpenter, 1976), however, most of that research emphasized on the role of other variables in changing the effect of attitude on behavior. Thus, Bagozzi et al. (1989) stated that attitude influences behavior directly as nonpurposeful reaction or indirectly through the intention as aimed response.

Researchers have discovered that attitudes can influence behavior directly as well as 
indirectly through intentions, like: Zuckerman and Reis (1978) (blood donation); Bentler and Speckart (1979) (consumption of alcohol, marijuana, and hard drugs); Bentler and Speckart (1981) (dating and exercise); Manstead et al. (1983) (infant feeding); Bonfield (1974) (fruit drinks). And Bentler and Speckart (1981) found substantial and statistically significant effects of negative attitudes on studying behavior, controlling for behavioral intentions. In sum, these studies suggest that intentions may not completely mediate the effects of attitudes on behavior, and may even be less important as a determinant of behavior.

Several studies showed evidence that attitudes and subjective norms are correlated. The studies were conducted by: Warshaw (1980), Ryan (1982), Shimp and Kavas (1984), Vallerand et al. (1992), Greene et al. (1997), Chang (1998), and Kim et al. (2009). The impact of the existence of a positive relationship between attitude and subjective norms is quite clear, namely: individuals who have a positive subjective norms toward the desired behavior, then they will tend to have a positive attitude toward the behavior (Chang, 1998; Aarts et al., 1998). Likewise individuals who have a negative subjective norm will tend to have a negative attitude toward a particular behavior (Chang, 1998; Aarts et al., 1998). O'Keefe (1990) argued that attitude and subjective norms were significantly and positively correlated. Moreover, his research may also reflect that attitude mediated, to some degrees, the relationship between norms and intention. Greene et al. (1997) argued also that it was not hard to envision an instance where perception of the attitudes of significant others influences a young person's own attitudes which, in turn, influence intention.

According to TPB, subjective norms are measured in terms of the respondent's beliefs that their most significant others think they should or should not perform the behavior in question. As this research shows that Indonesian bodybuilders have their significant others (namely instructors and colleagues, i.e. people who are most important to them) who, in turn, influence their attitude toward using AAS.
The present research examined the directly causal links of attitude toward behavior. Norman (1975) argued that attitudes caused behaviors. Bem (1972) argued also that behaviors caused attitudes. More over, Kelman (1974) argued also that attitudes and behaviors had mutual causal impact, and attitudes and behaviors were slightly, if at all, related (Wicker, 1969). In spite of a lack of theoretical agreement, progress is being made in identifying the attitude behavior relations. Accordingly, this research discovers that some of Indonesian bodybuilders have positive attitudes toward the using of AAS which, in turn, influence their behavior in using AAS.

Another objective of our study was to test causal links that have not been included in the TPB model. The TPB predicts that behavioral belief will affect one's attitude. The question is, where do the bodybuilders get these beliefs? Possible sources, and quite reasonably so, are their instructors, colleagues, families, etc. In short, they are the person's significant others. If this is true, the effect of the significant others on attitude formation cannot be ignored. In the sport of bodybuilding, colleagues may affect greatly the AAS use behavior of a bodybuilder, both through social pressure and formation of attitudes.

\section{Value and Attitude toward Behavior}

Several definitions of 'value' exist in various contexts. In one instance, value is considered the consumer's overall assessment of the utility of a product based on perceptions of what is received and what is given (Sheth et al., 1991), which focuses on consumer benefits or the worth of using a product. In another instance, value is defined as a belief about desirable end states (Rokeach, 1973; Schwartz, 1994), which focuses on a psychological aspect. The term value in this research reflects the latter, which is viewed as the most fundamental element of an individual's belief system (Vaske \& Donnelly, 1999).

Schwartz and Bardi (2001) defined values as desirable, transsituational goals, varying in importance, that serve as guiding principles in people's lives. Previous studies have shown that 
values relate to choice behavior in real life situations (Schwartz \& Bardi, 2001). For example, values predicted choosing a university course (Feather, 1988) and voting for political parties (Schwartz, 1996). These are examples of behaviors that people choose carefully, after weighing the pros and cons of alternatives. In such choice situations, values are likely to come to mind and influence decisions. Connor and Becker (2003) argued that values are likely to influence behavior only when behavior stems from conscious decisions.

Some hold that values guide behavior and even include this guiding role in their definition of values (Rokeach, 1973). Others conclude that values guide behavior only rarely and not for most people (e.g., Schwartz, 1996; Schwartz \& Bardi, 2001). Numerous empirical studies link values to behavior. Most of these, however, examine single behaviors (e.g., Rokeach, 1973; Schwartz, 1996) or sets of behavior presumed to express one content domain of values (e.g., prosocial behavior, Bond \& Chi, 1997; religiosity, Schwartz \& Huismans, 1995). It is still unclear whether values relate to behavior generally, or only that some values relate to some behaviors.

Values tend to influence the attitude and behavior as defined by Schwartz (1994) that value can motivate the action of giving direction, emotional intensity and has a function as a standard to assess and justify the action. Similarly, in this research, the writer focuses on one value variable from ten values which is stated by Schwart (1994), namely achievement. As stated by Schwartz, (1994), achievement is personal success through demonstrating competence according to social standards.

As mentioned earlier, attitudes toward a specific behavior refer to personal evaluations being favorable or unfavorable to perform the behavior (Schifter \& Ajzen, 1985; Ajzen \& Madden, 1986; Ajzen, 1991). Accordingly, values may influence formation of an individual's attitude by guiding him/her to look for objects that will satisfy his/her values (Grunert \& Juhl, 1995; Poortinga et al., 2004). For example, people who value a healthy life may have favorable attitudes toward objects that contribute to a healthy life (i.e. fitness club, dietary supplement, healthy food, etc.). Research has shown that values may provide a basis for consumers' evaluations and consumers' preferences for products (Allen, 2002).

Given the fact that values influence consumer attitudes, we need to know what kinds of values are related to Indonesian bodybuilders' attitudes toward using AAS. According to the relevant literature on steroid consumption, it appears that values concerned with improving performance and providing a competitive edge influence attitudes toward using AAS (Barkoukis et al., 2011; Boardley \& Grix, 2014). These values are proposed to be relevant to AAS use because the products are related to becoming a logical option for Indonesian bodybuilders intent on winning championship medals (Monaghan, 2002) as discussed below. In addition, unlike other products, AAS affect Indonesian bodybuilders' appearances (bigger muscles, higher endurance, and no overtraining) and Barkoukis et al. (2011) said that bodybuilders use these products to manage their appearances. Therefore, the current research proposes one Indonesian bodybuilders value that may influence attitudes toward using AAS: achievement. Moreover, this research expects that Indonesian bodybuilders with value systems will show different behaviors toward using of AAS because one's values, such as achievement (Rokeach, 1973), related to seeking personal success for oneself. So the hypotheses which are proposed in this research are:

H1 : bodybuilders with higher, more favorable, attitude toward AAS reuse will correspond to a greater intention to reuse AAS in a month before the bodybuilding championship.

$\mathrm{H} 2$ : bodybuilders with higher, more favorable, attitude toward AAS reuse will correspond to a greater the AAS reuse in a month before the bodybuilding champioship.

H3: bodybuilders with higher subjective norms will correspond with a more favorable, attitude toward AAS reuse. 
H4: bodybuilders with higher subjective norms will correspond with a greater intention to reuse AAS in a month before the bodybuilding championship.

H5: bodybuilders with higher perceived behavioral control will correspond with a greater intention to reuse AAS in a month before the bodybuilding champioship.

H6: bodybuilders with higher values will correspond with a more favorable, attitude toward AAS reuse.

H7: bodybuilders with higher intention will correspond to a greater the AAS reuse in a month before the bodybuilding championship.

These Hypotheses can be visualized in Figure 1.

\section{METHODS}

This research consisted of two stages: the first stage was qualitative and the second stage was quantitative. In the first stage, we conducted an elicitation study (exploratory) on a representative sample of the population. A standard procedure for identifying attributes or outcomes associated with an attitude, subjective norms, and perceived behavioral control (Fishbein \& Ajzen, 1975; Ajzen \& Fishbein, 1980; Ajzen, 1991) and values which were adopted by Indonesian bodybuilders related to AAS use behavior.

In the first stage, we conducted an interview with 25 Indonesian bodybuilders as key informants. The interview method which was imple- mented by the writers used an ethnography approach that was a research activity for understanding the way people communicate and corporate through observed phenomena in daily life (Ybema et al., 2009). The determination of key informants in this stage is based on these considerations: (1) they are profesional bodybuilders; (2) they follow bodybuilding championships, (3) they have knowledge about AAS, (4) they have used AAS for more than one year, and (5) they are willing to participate in this research.

After an interview, the transcript of the recording of the coversation with the key informant was created. These transcripts were made were made with the help of a colleague at the Research and Training Institute for Economics and Business, Economics and Business Faculty, Gajah Mada University (P2EB FEB UGM ). The transcripts which had been created were analyzed using content analysis. A content analysis and count of these open-ended responses allows one to identify the attributes or outcomes set. More specifically, the set is comprised of those attributes or outcomes that are mentioned most frequently by the population being considered. One rule of thumb is to include all attributes or outcomes mentioned by at least ten percent of the sample. Those attributes or outcomes that are elicited most frequently are included in the modal set and are used as the basis for the quantitative measures of attitude, subjective norm, and perceived behavioral control.

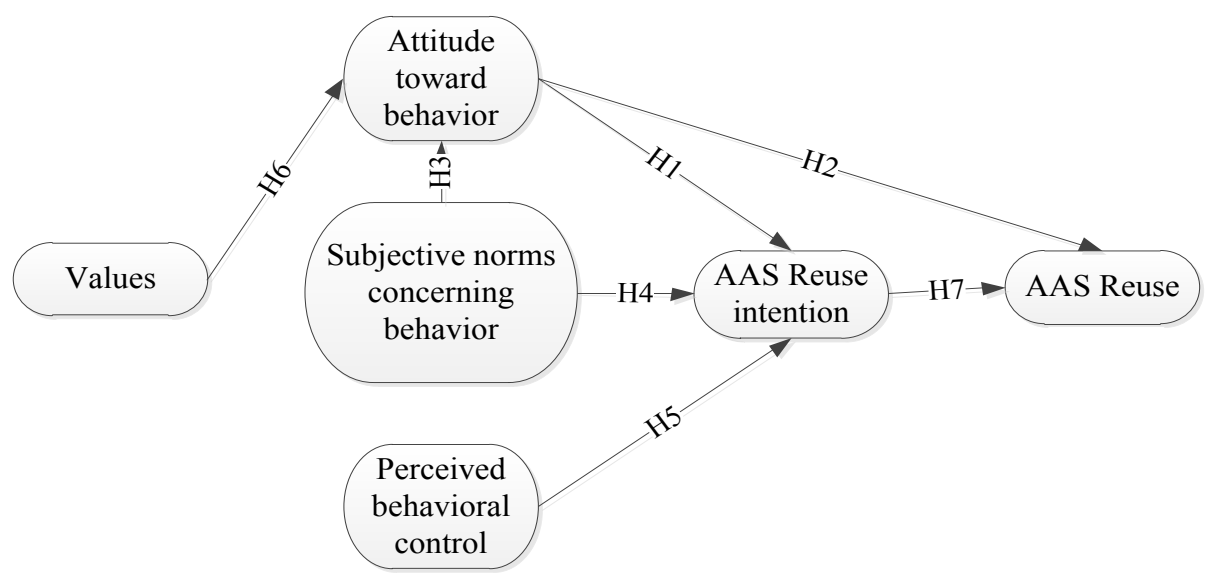

Figure 1. Proposed research model 
Kassarjian (1977) suggested that a validity test in content analysis could used fopr content validity or face validity. In this research, a face validity test was conducted by asking for input for the coding sheet from the researcher at P2EB FEB UGM. The result of this input was then used to complete coding sheet.

Besides face validity testing, the coding sheet must also have high reliability. The aim of this test was to know whether the coding sheet could produce the same findings when it was conducted with other people. In this research, the reliability test was conducted by counting the magnitude of the reliability coefficient, Holsti (1963) stated the formula as follows:

$2(C 1,2) C 1+C 2]$

\section{$\mathrm{C} 1,2=$ the number category approved of assessment result (considered similar) by all coders \\ $\mathrm{C} 1, \mathrm{C} 2=$ the number of all categories which is used by all coders.}

In this research, an inter coder reliability test was conducted by assignment of students in Economics and Business Faculty at Gajah Mada University. From this test, the magnitude of reliability coefficient was 0.88 . It was categorized good, because of more than 0.6 (Holsti, 1963), means that interpretation of a interview results for a different person was similar.

From the interview result, it can be seen that AAS use behavior among Indonesian bodybuilders has been common. Beyond the scope of bodybuilding sports performance, improving appearance is also among the reasons for using AAS while ignoring the health threat that might be posed by using it. Interestingly, many Indonesian bodybuilders see AAS as a necessary means to an end and do not consider using performance enhancement as 'cheating'. It is probably the case because Indonesian bodybuilders do not take the drug to replace hard work and training, but rather to add the extra edge to the work they have already done in order to increase the probability of winning, and having something valuable in return.
The stage two is quantitative which aimed to discovered the effect of TPB variables (attitude, subjective norms, perceived behavioral control, and intention) toward bodybuilder's behavior in using AAS. In the extended TPB model, we added an additional variable, namely the values adopted which influenced the attitudes toward using AAS, and formed causal links from subjective norms concerning using AAS behavior to attitude. In this stage, we conducted questionnaire preparation based on the interview result with key informants. The questionnaire contained variables of attitude, subjective norms, perceived behavioral control, intention, behavior, and value. After conducting back translation for the items in the questionnaire, a socially desirable response test was done. The aim of the test related to respondent dishonesty in giving information, and it had become a concern of the researchers.

Further, after the test gave the proper result as expected, the construct validity test (convergence and discriminant) for variable used was conducted. Moreover, after the result of construct validity test was obtained and was in accordance as expected, we conducted a multivariate regression analysis to discover the effect of TPB variables and the added variable (value) for understanding, explaining, and predicting Indonesian bodybuilders' behavior in using AAS.

\section{Population and sample}

This research attempts to use a definite sample $(\mathrm{N}=500)$ based on previous studies on TPB where the range is between 34 and 1009 respondents in maximum (Sheppard et al., 1988). Moreover, we also faced a difficulty because of the limited number of Indonesian professional bodybuilders who were willing to speak in an honest way about being AAS users. As our experience in the field, the using of AAS in Indonesia has been commonplace, but its use is still considered taboo although, in fact, a lot of people use it, especially for Indonesian bodybuilders who tended to admit that they were a natural bodybuilder. The participants were professional bodybuilders who are located in Jakarta, Bandung, Surabaya, and Yogyakarta. 
The questionnaires distributed to respondents were appropriate with predetermined categories, such as: (1) man aged $>23$ years, (2) They have used AAS for more than one year, (3) they are professional bodybuilders, (4) they were going to participate in the Regional Championship "Kejuaraan Daerah Persatuan Angkat Besi, Angkat Berat, dan Binaraga Seluruh Indonesia/ KEJURDA PABBSI" which was held on 13-14 June 2015 in Yogyakarta.

We found those respondents through the assistance of key informants who had been interviewed previously. The questionnaire was distributed to Indonesian bodybuilders which located in Bandung, Jakarta, Surabaya, and Yogyakarta. This research used two stages or two time interval for collecting the data by questionnaire. The first stage, from 19 March 2015 until 14 May 2015, was a measurement for value, attitude, subjective norms, perceived behavioral control, and behavioral intention to use AAS. The second stage, which held between 3 August 2015 and 12 September 2015 was a measurement for AAS reuse behavior.

A total of 500 questionnaires in first stage were collected for this research. Of these, 100 questionnaires were deemed suspect and were subsequently discarded. These were questionnaires that had a consistent case of "columnchecking" of scales with reverse items or questionnaires that had one or more pages left unanswered. A total of 400 questionnaires in second stage were therefore administered for this research. Of these, 30 questionnaires were deemed suspect and were subsequently discarded at this stage. Of the remaining 370 questionnaires, 20 had missing data. These questionnaires had at least one missing value item (no more than two missing items per questionnaire were detected).

Since the number of missing items was relatively low (1-4 items per questionnaire), and since all of the missing values were independent variables, the missing variable values were estimated (Schwab, 1999). According to Schwab (1999), mean estimation is the most popular method to estimate missing values. This is accomplished by replacing the missing values with the mean for that variable across the subjects. Consequently, a total of 370 questionnaires were deemed acceptable for use in this study.

\section{Sample Characteristics}

Table 1. Sample Characteristics

\begin{tabular}{cccc}
\hline Variables & Categories & Sum & Percentage \\
\hline \multirow{2}{*}{ Gender } & Male & 370 & 100 \\
& Female & 0 & 0 \\
& $25-30$ years & 30 & 8.11 \\
& $31-35$ years & 100 & 27.03 \\
Age & $36-40$ years & 160 & 43.24 \\
& $41-45$ years & 55 & 14.86 \\
& $46-50$ years & 25 & 6.76 \\
& Less than $160 \mathrm{~cm}$ & 60 & 16.22 \\
Height & $161-170 \mathrm{~cm}$ & 135 & 36.49 \\
& $171-180 \mathrm{~cm}$ & 100 & 27.03 \\
& $181-190 \mathrm{~cm}$ & 75 & 20.27 \\
& $121 \mathrm{lbs}$ & 30 & 8.11 \\
& $132 \mathrm{lbs}$ & 25 & 6.76 \\
& $143 \mathrm{lbs}$ & 55 & 14.86 \\
& $154 \mathrm{lbs}$ & 78 & 21.08 \\
& $165 \mathrm{lbs}$ & 80 & 21.62 \\
& $187 \mathrm{lbs}$ & 52 & 14.05 \\
& More than $187 \mathrm{lbs}$ & 50 & 13.51 \\
\hline
\end{tabular}




\begin{tabular}{|c|c|c|c|}
\hline Marital Status & $\begin{array}{l}\text { Single } \\
\text { Married }\end{array}$ & $\begin{array}{l}259 \\
111\end{array}$ & $\begin{array}{l}70 \\
30\end{array}$ \\
\hline Occupation & $\begin{array}{c}\text { Public Servant } \\
\text { Security Officer } \\
\text { Businessman } \\
\text { Employee } \\
\text { Student } \\
\text { Athlete }\end{array}$ & $\begin{array}{c}7 \\
4 \\
57 \\
60 \\
30 \\
212\end{array}$ & $\begin{array}{c}1.89 \\
1.08 \\
15.41 \\
16.22 \\
8.11 \\
57.30\end{array}$ \\
\hline Education & $\begin{array}{l}\text { High School } \\
\text { Bachelor } \\
\text { Postgraduate }\end{array}$ & $\begin{array}{c}200 \\
110 \\
60\end{array}$ & $\begin{array}{l}54.05 \\
29.73 \\
16.22\end{array}$ \\
\hline Income per month & $\begin{array}{c}\operatorname{Rp} 0-\operatorname{Rp} 1.000 .000 \\
\operatorname{Rp} 1.000 .001-\operatorname{Rp} 2.500 .000 \\
\operatorname{Rp} 2.500 .001-\operatorname{Rp} 5.000 .000 \\
\text { Rp 5.000.001-Rp } 10.000 .000 \\
\text { Higher than Rp } 10.000 .000\end{array}$ & $\begin{array}{c}0 \\
10 \\
90 \\
140 \\
130\end{array}$ & $\begin{array}{c}0 \\
2.70 \\
24.32 \\
37.84 \\
35.14\end{array}$ \\
\hline Training experience & $\begin{array}{l}\text { Less than } 1 \text { year } \\
\text { 1-3 years } \\
4-5 \text { years } \\
\text { More than } 5 \text { years }\end{array}$ & $\begin{array}{c}0 \\
12 \\
100 \\
258\end{array}$ & $\begin{array}{c}0 \\
3.24 \\
27.03 \\
69.73\end{array}$ \\
\hline $\begin{array}{c}\text { Experience of using } \\
\text { AAS }\end{array}$ & $\begin{array}{l}\text { Less than } 1 \text { year } \\
\text { 1-3 years } \\
4-5 \text { years } \\
\text { More than } 5 \text { years }\end{array}$ & $\begin{array}{c}0 \\
3 \\
98 \\
269\end{array}$ & $\begin{array}{c}0 \\
0.0081 \\
26.49 \\
72.70\end{array}$ \\
\hline
\end{tabular}

\section{Measurement}

Achievement value was measured, as suggested by Sagiv and Schwartz (2004), Schwartz (2007), and Schmidt et al. (2007), with a threeitem construct answered on a five-point scale. The items include "It's very important to me to show my abilities by winning championships. I want people to admire what I do", "I think it is important to be ambitious when participating in bodybuilding championships. I want to show how capable I am", "Getting ahead in bodybuilding is important to me. I strive to do better than others". In this research, achievement value was measured using three items and scored on a five-point scale ranging from strongly agree to strongly disagree.

Attitude is assessed with items relating to the overall favorableness/unfavorableness of the behavior. As suggested by Fishbein and Ajzen (1975), subjects are asked to respond to a question regarding the individual's attitude towards the behavior. Respondents are presented with the sentence, "Overall, my attitude towards using AAS is:", and semantic differential items are used to answer the question and assess attitude. Different semantic differential items that have been used include good/bad, favorable/unfavorable, pleasant/unpleasant, harmful/beneficial, useful/useless, positive/negative, pro/anti, harmful/beneficial, nice/awful, and wise/foolish among others (Ajzen \& Fishbein, 1980; Schifter \& Ajzen, 1985; Ajzen \& Madden, 1986; Ajzen, 2002). In this research, attitude is measured using four items (good/bad, harmful/beneficial, foolish/wise, and favorable/unfavorable) and scored on a five-point scale ranging from strongly agree to strongly disagree.

Subjective norms have been assessed by asking subjects whether "significant others" approve or disapprove of the behavior in question. Examples questions include "Most people who are important to me think that I should use AAS", and "When considering using AAS, I wish to do what the most significant people around me think", and answered using a five point Likert scale ranging from "strongly agree" to "strongly disagree" (Ajzen \& Fishbein, 1980; Schifter \& Ajzen, 1985; Ajzen \& Madden, 1986; 
Ajzen, 2002). In total, 4 items assessing subjective norms are used in this research.

Perceived behavioral control is a measure of how easy or difficult it is for subjects to perform the behavior in question as originally depicted by Ajzen and Fishbein (1980), Schifter and Ajzen (1985), Ajzen and Madden (1986), Ajzen (2002). Ajzen (2002) recommends the use of both a self efficacy measure (whether individuals believe that they have the skills and abilities to perform the behavior) and control (whether individuals believe they have control over performing the behavior) measures. Measures used in this research are based on measures used in previous research regarding perceived behavioral control that capture both self efficacy and control dimensions. Self efficacy will be measured on a five point scale assessing "If I wanted to, I could use AAS" (strongly agree/strongly disagree), and "I believe I have the ability to use AAS" (strongly agree/strongly disagree). Control will be measured also on a five point scale assessing "I have the resources necessary to use AAS" (strongly agree/strongly disagree), and "I can find AAS to use if I wanted to" (strongly agree/strongly disagree).

AAS reuse intention is measured, as suggested by Ajzen and Fishbein (1980), Schifter and Ajzen (1985), Ajzen and Madden (1986), Ajzen (2002), with a four-item construct answered on a five-point scale. The items include "I intend to use AAS again in the month before a bodybuilding championship" (definitely do/definitely do not), "I will try to use AAS again in the month before a bodybuilding championship" (definitely will/definitely will not), "I want to use AAS again in the month before a bodybuilding championship" (definitely yes/definitely not) and "I plan to use AAS again in the month before a bodybuilding championship" (definitely yes/definitely not).

AAS reuse was measured, as suggested by Ajzen (1991, 2002), with a two-item construct answered on a five-point scale. The items in- clude "Please estimate how often you have used AAS injections again for at least a month before you followed a bodybuilding champioship. Check the interval on the following scale that best represents your estimate". "Please estimate how often you have used AAS orally again for at least a month before you followed a bodybuilding champioship. Check the interval on the following scale that best represents your estimate. In total, two items assessing AAS reuse were used in this research.

\section{RESULTS}

\section{Socially Desirable Response}

In order to minimalize the response bias because of the filling in questionnaire by self reporting (Fisher, 2000; Chung \& Monroe, 2003), we conducted a Socially Desirable Response (SDR) test. The main reason is related to its topic, AAS use behavior among Indonesian bodybuilders. The topic is considered to be highly sensitive among health related behavior researchers. The SDR test was conducted using a non paired sample. It was conducted using non parametric statistics using the Mann Whitney test. The result showed the $p$ value which was more than 0.05 . It means that both samples (non paired) were coming from the population who had mean or the same expectation, which meant, the average respondent's answer from both samples was similar. For more explanation, see Table 2 .

\section{Reliability and Validity}

To establish construct validity, three components were examined (O'Leary-Kelly \& Vokura, 1998) namely unidimensionality, reliability, and validity. Confirmatory Factor Analysis (CFA) (Pedhauzr \& Schmelkin, 1991) was used to check unidimensionality. All the scales loaded on one factor. Overall, tests on these different scales provided evidence of the unidimensionality of the constructs used in this research. For more details, see Table 3 . 
Table 2. The Result of Socially Desirable Response Test

\begin{tabular}{llc}
\hline \multicolumn{1}{c}{ Construct } & Measurement Indicator & P Value \\
\hline \multirow{5}{*}{ Attitude } & Overall, my attitude towards using AAS is good/bad & 0.510 \\
& Overall, my attitude towards using AAS is harmful/beneficial & 0.824 \\
& Overall, my attitude towards using AAS is foolish/wise & 0.393 \\
& Overall, my attitude towards using AAS is favorable/ unfavorable & 0.759 \\
& Most people who are important to me think that I should use AAS & 0.510 \\
Subjective norm & When considering using AAS, I wish to do what most important people to & 0.824 \\
& me think & 0.634 \\
& If most people who are important to me use AAS, I will use also & 0.146 \\
If many people like me use AAS, I will use also & 0.347 \\
Perceived control & If I wanted to, I could use AAS & 0.742 \\
& I believe I have the ability to use AAS & 0.222 \\
& I can find AAS to use if I wanted to & 0.312 \\
Intention & I intend to use AAS again in a month before bodybuilding championship & 0.275 \\
& I will try to use AAS again in a month before bodybuilding championship & 0.900 \\
& I want to use AAS again in a month before bodybuilding championship & 0.883 \\
& I plan to use AAS again in a month before bodybuilding championship & 0.659 \\
& It's very important to me to show my abilities by winning championship. I & 0.878 \\
& want people to admire what I do & \\
& I think it is important to be ambitious when competing in bodybuilding \\
championship. I want to show how capable I am & 0.565 \\
Getting ahead in bodybuilding is important to me. I strive to do better than & 0.422 \\
& others & \\
\hline \multirow{5}{*}{ Value } & &
\end{tabular}

Table 3. The Result of Discriminant Validity Testing

\begin{tabular}{|c|c|c|c|c|c|}
\hline & \multicolumn{5}{|c|}{ Component } \\
\hline & 1 & 2 & 3 & 4 & 5 \\
\hline $\begin{array}{l}\text { Overall, my attitude towards using AAS is } \\
\text { good/bad }\end{array}$ & 0.971 & & & & \\
\hline $\begin{array}{l}\text { Overall, my attitude towards using AAS is } \\
\text { harmful/beneficial }\end{array}$ & 0.877 & & & & \\
\hline $\begin{array}{l}\text { Overall, my attitude towards using AAS is } \\
\text { foolish/wise }\end{array}$ & 0.957 & & & & \\
\hline $\begin{array}{l}\text { Overall, my attitude towards using AAS is } \\
\text { favorable/unfavorable }\end{array}$ & 0.949 & & & & \\
\hline $\begin{array}{l}\text { Most people who are important to me think that I } \\
\text { should use AAS }\end{array}$ & & 0.873 & & & \\
\hline $\begin{array}{l}\text { When considering using AAS, I wish to do what } \\
\text { most important people to me think }\end{array}$ & & 0.893 & & & \\
\hline $\begin{array}{l}\text { If most people who are important to me use AAS, I } \\
\text { will use also }\end{array}$ & & 0.867 & & & \\
\hline If many people like me use AAS, I will use also & & 0.892 & & & \\
\hline If I wanted to, I could use AAS & & & & 0.699 & \\
\hline I believe I have the ability to use AAS & & & & 0.747 & \\
\hline I have the resources necessary to use AAS & & & & 0.870 & \\
\hline I can find AAS to use if I wanted to & & & & 0.903 & \\
\hline
\end{tabular}


Table 3. The Result of Discriminant Validity Testing (con't)

\begin{tabular}{|c|c|c|c|c|c|}
\hline & \multicolumn{5}{|c|}{ Component } \\
\hline & 1 & 2 & 3 & 4 & 5 \\
\hline $\begin{array}{l}\text { I intend to use AAS again in a month before bodybuilding } \\
\text { championship }\end{array}$ & & & 0.824 & & \\
\hline $\begin{array}{l}\text { I will try to use AAS again in a month before } \\
\text { bodybuilding championship }\end{array}$ & & & 0.732 & & \\
\hline $\begin{array}{l}\text { I want to use AAS again in a month before bodybuilding } \\
\text { championship }\end{array}$ & & & 0.788 & & \\
\hline $\begin{array}{l}\text { I plan to use AAS again in a month before bodybuilding } \\
\text { championship }\end{array}$ & & & 0.685 & & \\
\hline $\begin{array}{l}\text { It's very important to me to show my abilities by winning } \\
\text { championship. I want people to admire what I do }\end{array}$ & & & & & 0.688 \\
\hline $\begin{array}{l}\text { I think it is important to be ambitious when competing in } \\
\text { bodybuilding champioship. I want to show how capable I } \\
\text { am }\end{array}$ & & & & & 0.795 \\
\hline $\begin{array}{l}\text { Getting ahead in bodybuilding is important to me. I strive } \\
\text { to do better than others }\end{array}$ & & & & & 0.697 \\
\hline
\end{tabular}

Composite reliability is used as a measure of reliability (Pedhauzr \& Schmelkin, 1991). It can gain a better estimate while Cronbach's alpha, with its assumption of parallel measures, represents a lower bound estimate of internal consistency (Salisbury et al., 2002; Hartono \& Abdillah, 2009, pp. 132). An alpha value of 0.6 and above has been used as a lower limit for reliable measures (Nunnaly, 1978). All of the scales were shown to be reliable (with all scales having a composite reliability value above 0.8 ) (see Table 4).

The final step in establishing construct validity is the establishment of convergent and discriminant validity. Convergent validity is a measure of how well the items load on their corresponding factors. Discriminant validity on the other hand, is demonstrated by checking the correlations between the factors, and whether they are significantly different (Pedhauzr \& Schmelkin, 1991). Convergent validity is checked by examining the significance of item loadings on their corresponding factor (Confirmatory Factor Analysis, CFA) for each of the scales in the study (Pedhauzr \& Schmelkin, 1991). Each of the scales demonstrated convergent validity.

Table 4 summarizes the factor, reliability, and convergent analyses results for the appropriate components. It showed that convergence validity for each construct was good. It can be seen from AVE value which exceed 0.5 (Hair et al., 2010, pp. 709; Chin, 1998, pp. 298; Chin, 2010, pp. 658).

\section{Measurement Model Testing and Structural Model}

A Structured Equation Modeling (SEM) analysis was used to evaluate the structural or path model. SEM (Gefen et al., 2000) is used in this analysis to confirm the theory. This study utilized the AMOS 21.0 software package to analyze the model. Table 5 and Table 6 presents the AMOS 21.0 results of the analysis. The SEM results for extended TPB model that includes values in addition to the TPB model components are presented.

Tabel 4. The Result of Convergence Validity and Reliability

\begin{tabular}{lccc}
\hline \multicolumn{1}{c}{ Construct } & AVE & Composite Reliability & Cronbach Alpha \\
\hline Attitude & 0.622 & 0.868 & 0.797 \\
Subjective norm & 0.729 & 0.843 & 0.633 \\
Intention & 0.799 & 0.888 & 0.753 \\
Value & 0.571 & 0.841 & 0.752 \\
\hline
\end{tabular}




\begin{tabular}{|c|c|c|c|c|c|c|}
\hline \multicolumn{2}{|c|}{ Perceived behavioral control } & 0.810 & \multicolumn{2}{|c|}{0.895} & \multicolumn{2}{|c|}{0.766} \\
\hline \multicolumn{7}{|c|}{ Table 5. Correlations Among the Latent Construct } \\
\hline & Construct & 1 & 2 & 3 & 4 & 5 \\
\hline 1 & Attitude & 1 & & & & \\
\hline 2 & Subjective norm & $0.345 * *$ & 1 & & & \\
\hline 3 & Perceived control & $0.485 * *$ & $0.402 * *$ & 1 & & \\
\hline 4 & Values & $0.632 * *$ & $0.280 * *$ & $0.357 * *$ & 1 & \\
\hline 5 & Intention & $0.515^{* *}$ & $0.263 * *$ & $0.571 * *$ & $0.396^{* *}$ & 1 \\
\hline 6 & Behavior & $0.228 * *$ & $0.132 * *$ & $0.286 * *$ & $0.146 * *$ & $0.432 * *$ \\
\hline
\end{tabular}

Achievement value had a significant effect on attitude; attitude and perceived behavioral control had a significant effect on behavioral intention; and behavioral intention had a significant effect on behavior. Paths are all significant at the 0.001 level. Attitude had a significant effect on behavior, subjective norms had a significant effect on attitude, and behaviral intention. Paths are all significant at the 0.05 level. Table 6 summarizes the results of the SEM analysis as follows. To asses the fit of the model, a quick examination of the fit indices is required as follows (as suggested by Hair et al., 2010). Comparative Fit Index (CFI): values larger than 0.90 indicate good fit - Normed Fit Index (IFI),): values larger than 0.90 indicate good fit Goodness of Fit Index (GFI) and Adjusted Goodness of Fit Index (AGFI): values larger than 0.90 indicate good fit, and - Root Mean Square Error of Approximation (RMSEA): values between 0.05 and 0.08 indicate good fit. Similarly, from fit model testing was obtained the result as follows: $\mathrm{CMIN} / \mathrm{DF}=2.140$; RMSEA $=0.051 ;$ GFI $=0.953$; AGFI $=0.930$; $\mathrm{RMR}=0.051 ; \mathrm{NFI}=0.925 ; \mathrm{CFI}=0.958$. Table 6 showed that from seven hypotheses proposed, all of them were supported (Hypothesis one (H1), Hypothesis two (H2), Hypothesis three (H3), Hypothesis four (H4), Hypothesis five (H5), Hypothesis six (H6), and Hypothesis seven (H7)). Examining the results of the SEM analysis, attitude was a significant predictor of intention. As hypothesized, there was a positive relationship between attitude and intention. Hypothesis one (H1) is then not rejected, and we conclude that Indonesian bodybuilders with high (more favorable) attitude to use AAS tend to have a higher intention towards using AAS ( $\mathrm{p}<$ 0.001). Hypothesis two (H2) stated, there was a positive causal link between attitude and behavior directly. Hypothesis two (H2) is then not rejected, and we conclude that Indonesian bodybuilders with high (more favorable) attitude toward using AAS tend to use AAS again ( $\mathrm{p}<$ $0.05)$. Hypothesis three $(\mathrm{H} 3)$ and four $(\mathrm{H} 4)$ stated, subjective norms were a significant predictor of attitude and intention. There was a positive significant relationship between subjective norm, attitude, and intention. Hypothesis three (H3) and four (H4) is not rejected. We conclude that Indonesian bodybuilders' attitude and intentions regarding using AAS are positively affected by the approval of significant others $(\mathrm{p}<$ 0.05). Perceived behavioral control was hypothesized to positively affect the intention towards using AAS (Hypothesis five (H5)). Examining the results of the analysis, perceived behavioral control was a significant predictor of intention. As expected, there was a positive relationship between perceived behavioral control and intention. Hypothesis five (H5) is not rejected, and we conclude that Indonesian bodybuilders that have the ability and resources to use AAS will tend to have a higher intention towards using AAS $(\mathrm{p}<0.001)$. Hypothesis six (H6) stated, values were a significant predictor of attitude. Hypothesis six (H6) is then not rejected, and we conclude that Indonesian bodybuilders' attitudes regarding using AAS is positively affected by the achievement value which they adopted $(\mathrm{p}<0.001)$. Behavioral intention was hypothesized to positively affect the AAS reuse (Hypothesis seven). Examining the results of the analysis, behavioral intention was a significant predictor of behavior. As expected, there was a positive relationship between behavioral intention and behavior. Hypothesis seven (H7) is not rejected, and we conclude that Indonesian bodybuilders that have the higher intention to use AAS will tend to use AAS again $(\mathrm{p}<0.001)$. 
Table 6. The Result of Measurement and Structural Model Testing

\begin{tabular}{cccc}
\hline Hypothesized Path & Standardized Path Coefficients & t-value & Results \\
\hline H1 & 0.393 & $5.018^{* * *}$ & Supported \\
H2 & 0.313 & $3.127^{* *}$ & Supported \\
H3 & 0.212 & $2.368^{* *}$ & Supported \\
H4 & 0.359 & $2.650^{* *}$ & Supported \\
H5 & 0.736 & $8.134^{* * *}$ & Supported \\
H6 & 0.923 & $4.416^{* * *}$ & Supported \\
H7 & 0.805 & $6.448^{* * *}$ & Supported \\
\hline Notes: **. Significant at $\mathrm{p}<0,05 ; * * *$ Significant at $\mathrm{p}<0,001$ & &
\end{tabular}

\section{CONCLUSION}

The present research set out to identify the psychosocial predictors of using AAS by using an extended TPB model which accounted especially for the operation of normative processes. This research shows that most of the determinants included in our framework significantly correlated with the use of AAS. Four social psychological determinants proved to be the most relevant to use AAS: attitude, subjective norms, perceived behavioral control, and intention.

With regard to achievement value, the results indicated that Indonesian bodybuilders generally share the same value about using AAS again. Their personal value about using these drugs again were more restricted in the month before they followed championship bodybuilding. Indonesian bodybuilders who use this drugs anticipated more positive effects of these drugs on their performance than non-users. They believed their bodies would become more powerful, more muscled and better shaped. They also believed that these valued outcomes would be achieved in a shorter period of time than if they used no drugs at all.

Further, in line with the expectations of the research, TPB variables significantly predicted AAS reuse intentions, and intention to reuse AAS signficantly predicted AAS reuse. Specifically, attitudes, subjective norms, and perceived behavioral control retained significant effects, even after controlling for the effects of other predictors, such as value. In line with previous research (e.g., Lucidi et al., 2004), the present findings suggest that perceived behavioral control play an important role in shaping proAAS reuse intentions.

In this research, the finding also indicated that attitude strongly predicted and may be predictive of future AAS reuse. In the present case, intentions seem to be an insufficient mediator of AAS use in particular. At the very least, the present results force one to view Fishbein and Ajzen's (1975, pp. 372) claim that intentions may be considered as the "immediate determinants of the corresponding overt behaviors" to be accurate only in a limited or incomplete sense. We conclude that Indonesian bodybuilders' attitude toward using AAS is able to influence their AAS reuse directly because there is achievement value which is adopted for reaching their certain purpose (more powerful, more muscled and better shaped).

The result of this research differs from Bagozzi et al. (1989) who stated that attitude can influence behavior, either directly or indirectly (mediated by behavioral intention). Further, they stated that behavior influenced directly by attitude is the effect of nonpurposeful reaction while conversely (through intention) is the effect of aimed response. The result of this research shows that attitude can influence behavior directly as the effect of purposeful reaction. This research suggests that intention is not a necessary and sufficient cause of behavior.

Contrary to the TPB model, this research shows that intentions do not completely mediate the effect of attitudes on behavior. This may occur because intentions are unstable and frequently not formed until immediately before behaving (Fredricks \& Dosset, 1983). This research also shows that attitudes do not 
mediate, completely, the effect of cognitions on intentions. This may occur because cognitions are frequently too complex and the cognitive processing capacities of people are too imperfect for cognitions to be completely processed into attitude (Liska, 1984).

Subjective norms are identified as the only variable, other than attitudes, that independently affects intentions. Although attitudes and subjective norms can be independently defined, this research suggests that they are not causally independent. They appear to reflect similar beliefs and to influence each other. The significant causal path from subjective norm to attitude suggests that the attitude formation, that is the favorableness or unfavorableness towards the behavior, is affected by how significant others consider the performance of the behavior.

TPB predicts that behavioral belief will affect one's attitude. The question is related to our context: where do the Indonesian bodybuilders get these beliefs? Possible sources, and quite reasonably so, are their instructors, colleagues, peers, etc. In short, they are the person's significant others. If this is true, the effect of the significant others on attitude formation cannot be ignored. Then, the Indonesian bodybuilders' attitude toward using AAS might have a causal link directly to use AAS again in the month before a bodybuilding championship. These results differ from Titah and Barki (2009), as suggested by Chang (1998) and Aarts et al. (1998), a person whose positive subjective norms toward overt behavior, will lead to positive attitude toward the behavior.

\section{THEORETICAL CONTRIBUTIONS}

Although it was not our intention to validate the TPB, the results indicated the added value of achievement values. While these are not explicitly accounted for by the TPB, our research indicates that they are strongly related to the intention to use AAS and AAS reuse indirectly which are mediated by attitude toward using AAS. This suggests that achievement values should be included in the theory of planned behavior especially in behaviors that are controversial, such as the use of performance- enhancing drugs. Other studies have also confirmed that achievement values may be as important as a predictor of attitude toward behavior (e.g. Kim (2009); Han et al. (2010); Chan \& Bishop (2013); Chen \& Tung (2014)).

As well as being based on an earlier study conducted among elite athletes, the operationalization of our framework was underlain by review of the literature and individual interviews with profesional bodybuilders. Like Berning (2003) and Goulet et al. (2010), we found that the use of AAS was predicted by attitudes, subjective norms, and perceived behavioral control. The difference between their study and ours is that we asked more detailed questions on these determinants and therefore our results might provide greater focus for intervention programs.

Some determinants we found were congruent with the framework of Donovan et al. (2002) though others were not. We found some empirical evidence for factors that are also in their model, e.g. values adopted, the opinion of significant others, and the advantages and disadvantages of using performance enhancing drugs. The interviews in elicitation study showed, as we had expected, that threats of detection and sanctions are not an issue for Indonesian bodybuilders. These may be relevant to elite bodybuilders only. As Flay and Petraitis (1994) have argued in their research, unlike proximal factors, distal factors may be associated with multiple health related behaviors, but their association with a single behavior will be weaker compared with proximal determinants as accounted for by our framework. We focused mainly on proximal determinants in order to find a maximum of explained variance in the use of $\mathrm{AAS}$, in determinants that are liable to health related behavior.

\section{RESEARCH IMPLICATIONS}

As is the case with any research, varied and interesting results from this research provide new tracks for future research directions. Future research directions are suggested within these areas: (1) research verification, (2) the role of values, (3) enhancement the extended TPB 
model and (4) further research on the antecedents of these components. To verify the results of this research, it should be replicated with a larger and a possibly different sample. A different sample would be beneficial to determine if these results would differ across different populations. A more diverse sample might be appropriate, with different age groups, different cultures, and non bodybuilders as subjects. The role of values also warrants further research. In particular, is there an effect of value on subjective norms, and perceived behavioral control? How does this effect (if at all) change in the model? It is important to understand the influence of attitude toward behavior on later behavior directly. Further research is needed to discovered the role of "other" variables in altering the effect of attitudes on behavior directly. Future research directions are also needed in the area of enhancing the extended TPB model. For example, in line the context of this research, should future TPB research include values as a predictor of intention (along with the other variables)? In addition, to more fully understanding using AAS behavior, a more comprehensive model should be studied. Cronan and Rafee (2006) present a comprehensive theoretical model which includes other components such as the moral obligation and past behavior among others. Antecedents of the components in this research should provide more insight into why bodybuilders have such predispositions to use steroid. By identifying what makes bodybuilders have a favorable attitude towards using AAS, one can better understand the formation of attitude and thus how might that be changed.

This original manuscript is a part of Dissertation (Indonesian Bodybuilders Behavior Model of The Use of Anabolic Androgenic Steroid). Economics and Business Faculty Universitas Gadjah Mada

\section{No Conflict of Interest}

\section{REFERENCES}

Aarts, H. B., T. Paulussen, and H. Schaalma, 1997. "Physical Exercise Habit: On The Conceptualization and Formation of Habi- tual Health Behaviors". Health Education Research, 12 (3), 363-374.

Ajzen, I., 2002. "Perceived Behavioral Control, Self Efficacy, Locus of Control, and The Theory of Planned Behavior". Journal of Applied Social Psychology, 32, 665-683.

1991. "The Theory of Planned Behavior". Organizational Behavior and Human Decision Process, 50, 179-211.

Ajzen, I. and M. Fishbein, 1980. Understanding Attitudes and Predicting Social Behavior. Englewood-Cliffs, NJ: Prentice-Hall.

and T. J. Madden, 1986. "Prediction of Goal Directed Behavior: Attitudes, Intentions, and Perceived Behavioral Control". Journal of Experimental Social Psychology, $22,453-474$

Alaranta, A., H. Alaranta, J. Holmila, P. Palmu, K. Pietila, and I. Helenius, 2006. "Self Reported Attitudes of Elite Athletes towards Doping: Differences between Type of Sport". International Journal of Sports Medicine, 27, 842-846.

Albrecht, S. L. And K. E. Carpenter, 1976. "Attitudes as Predictors of Behavior Versus Behavior Intentions: A Convergence of Research Traditions". Sociometry, 39, 1, 110.

Allen, M.W., 2002. "Human Values and Product Symbolism: Do Consumers Form Product

Preference by Comparing The Human Values Symbolized by A Product to Human

Values that They Endorse". Journal of Applied Social Psychology, 32 (12), 2475-2501.

Amsterdam, J. V., A. Opperhuizen, and F. Hartgens, 2010. "Adverse Health Effects of Anabolic Androgenic Steroids". Regulatory Toxicology and Pharmacology, 57, 117123.

Anshel, M.H., and K. G. Russell, 1997. "Examining Athletes' Attitudes toward Using Anabolic Steroids and Their Knowledge of The Possible Effects". Journal of Drug Education, 27, 121-145.

Armitage, C.J. and M. Conner, 2000. "Social Cognition Models and Health Behavior: A Structured Review". Psychology \& Health, 15, 173-189. 
Aronson, E., T. D. Wilson, and A. M. Akert, 2005. Social psychology. $5^{\text {th }}$ ed. Upper Saddle River, NJ: Prentice-Hall.

Bagozzi, R. P., J. Baumgartner, and Y. Yi, 1989. "An Investigation Into The Role

of Intentions as Mediators of The AttitudeBehavior Relationship". Journal of Economic Psychology. 10, 35-62.

Bardi, A. and S. H. Schwartz, 2003. "Values and Behavior: Strength and Structure of Relations". Personality and Social Psychology Bulletin, 29, 1207-1220.

Barkoukis, V., L. Lambros, T. Haralambos, and R. Angelos, 2011. "Motivational and Sportspersonship Profiles of Elite Athletes in Relation to Doping Behavior". Psychology of Sport and Exercise, 12, 205-212.

Bem, D. J., 1972. "Self Perception Theory" in: L. Berkowitz ed, Advances in Experimental Social Psycholog, 6, 1-62. New York: Academic Press.

Bentler, P.M. and G. Speckart, 1979. "Models of Attitude-Behavior Relations". Psychological Review, 86 (5), 452-464.

Bentler, P.M. and G. Speckart, 1981. "Attitudes "Cause" Behaviors: A Structural Equation Analysis". Journal of Personality and Social Psychology, 40 (2), 226-238.

Berning, J. M., 2003. "Characteristic Attitudes and Normative Factors of Anabolic Steroid Use among College Aged Males and Females: An Application of The Theory of Reasoned Action", Unpublished Dissertation, Interdepartmental Area of Psychological and Cultural Studies. University of Nebraska.

Bonfield, E. H., 1974. "Attitude, Social Influence, Personal Norm, and Intention Interactions as Related to Brand Purchase Behavior". Journal of Marketing Research, 11 (4), 379-389.

Bond, M. H. and V. M. Y. Chi, 1997. "Values and Moral Behavior in Mainland China". Psychologia, 40, 251-264.

Chan, L. and B. Bishop, 2013. "A Moral Basis for Recycling: Extending The Theory of Planned Behavior". Journal of Environmental Psychology, 36, 96-102.

Chang, M. K., 1998. "Predicting Unethical Behavior: A Comparison of The Theory of
Reasoned Action and The Theory of Planned Behavior". Journal of Business Ethics. 17 (16), 1825-1834.

Chen, M. F. and P. J. Tung, 2014. "Developing An Extended Theory of Planned Behavior Model to Predict Consumers' Intention to Visit Green Hotels". International Journal of Hospitality Management, 36, 221- 230.

Chin, W. W., 1998. "Modern Methods for Business Research" in: G. A. Marcoulides ed. The Partial Least Square Approach for Structural Equation Modeling, 295-336. London: Lawrence Erlbaum Associates.

Chin, W.W., 2010. "Handbook of Partial Least Squares: Concepts, Methods and Applications in Marketing and Related Fields" in: V. E. Vinzi, W. W. Chin, J. Henseler, and H. Wangs ed, How to Write up and Report PLS Analysis. Berlin: Springer.

Chung, J. and G. S. Monroe, 2008. "Exploring Social Desirability Bias". Journal of Business Ethics, 44 (4), 291-302.

Cialdini, R.B., R. R. Reno, and C. A. Kallgren, 1990. "A Focus Theory of Normative Conduct: Recycling The Concept of Norms to Reduce Littering in Public Places". Journal of Personality and Social Psychology, 58, 1015-1026.

Cialdini, R. B., C. A. Kallgren, and R. R. Reno, 1991. "A Focus Theory of Normative Conduct: A Theoretical Refinement and Reevaluation of The Role of Norms in Human behavior" in: M. P. Zanna ed. Advances in experimental social psycho$\log y, 24,201-234$.

Connor, P. E. and B. W. Becker, 2003. "Personal Value Systems and Decision Making Styles of Public Managers". Public Personnel Management, 32 (1), 155-180.

Cronan, T. P. and S. A. Rafee, 2008. "Factors That Influence the Intention to Pirate Software and Media". Journal of Business Ethics, 78 (4), 527-545.

Donovan, R. J., G. Egger, V. Kapernick, and J. Mendoza, 2002. "A Conceptual Framework for Achieving Performance Enhancing Drug Compliance in Sport". Sports Medicine, 32, 269-284.

Feather, N. T., 1988. "Values, Valences, and Course Enrolment: Testing The Role of Personal Values Within an Expectancy Value 
Framework". Journal of Educational Psychology, 80, 381-391.

Fishbein, M. And I. Ajzen, 1975. Belief, Attitude,Intention, and Behavior: An Introduction to Theory and Research. Massachusetts: Addison-Wesley Publishing Company, Inc.

Fisher, R. J., 2000. "The Future of Social Desirability Bias Research in Marketing". Psychology and Marketing, 17 (2), 73-74.

Flay, B.R. and J. Petraitis, 1994. "The Theory of Triadic Influence: A New Theory of Health Behavior with Implications for Preventive Interventions". Advance of Medical Social, 4, 19-44.

Godin, G. and G. Kok, 1996. "The Theory of Planned Behavior: A Review of Its Applications to Health Related Behaviors". American Journal of Health Promotion, 11 (2), 87-98.

Goulet, C., P. Valois, A. Buist, and M. Cote, 2010. "Predictors of The Use of Performance-Enhancing Substances by Young". Clinical Journal of Sport Medicine, 20, 243-248.

Greene, K., J. L. Hale, and D. L. Rubin, 1997. "A Test of The Theory of Reasoned Action in The Context of Condom Use and AIDS". Communication Reports, 10 (1), 22-33.

Grunert, S. And H. J. Juhl, 1995. "Values, Environmental Attitudes, and Buying of Organic

Foods". Journal of Economic Psychology, 16 (1), 39-62.

Hair, J. F., W. C. Black, B. J. Babin, and R. E. Anderson, 2010. Multivariate Data Analysis. $7^{\text {th }}$ ed. Upper Saddle River, NJ: Pearson Education, Ltd.

Han, H., L. T. Hsu, and C. Sheu, 2010. "Application of The Theory of Planned Behavior to Green Hotel Choice: Testing The Effect of Environmental Friendly Activities". Tourism Management, 31, 325-334.

Hartono, J. M. and W. Abdilllah, 2009. Konsep dan Aplikasi PLS (Partial Least Square) Untuk Penelitian Empiris (PLS (Partial Least Square) Concept and Application for Empirical Research). $1^{\text {st }}$ ed. Yogyakarta: BPFE.

Holsti, O.R., 1963. The Quantitative Analysis of Content, in Content Analysis: A Handbook
With Application for the Study of International Crisis. J. A. Robinson ed. Nortwestern: Nortwestern University Press.

Kallgren, C. A., R. R. Reno, and R. B. Cialdini, 2000. "A Focus Theory of Normative Conduct: When Norms Do and Do Not Affect Behavior". Personality and Social Psychology Bulletin, 26, 1002-1012.

Kassarjian, H.H., 1977. "Content Analysis in Consumer Research". Journal of Consumer Research, 4, 8-18.

Kelman, H. C., 1974. "Attitudes Are Alive and Well and Gainfully Employed in The Sphere of Action". American Psychologist, 29, 310-324.

Kim, H., T. Kim, and S. W. Shin, 2009. "Modeling Roles of Subjective Norms and ETrust in Customers' Acceptance of Airline B2C E-Commerce Websites". Tourism Management, 30, 266-277.

Kompas, H. 2013. "Penggunaan Steroid Merebak [Spread of Steroid Using]", Monday, May 6, 1 .

Lapinski, M. K. and R. N. Rimal, 2005. "An Explication of Social Norms". Communication Theory, 15, 127-147.

Liska, A. E., R. B. Felson, M. Chamlin, and W. Baccaglini, 1984. "Estimating AttitudeBehavior Reciprocal Effects Within a Theoretical Specification". Social Psychology Quarterly. 47 (1), 15-23.

Lucidi, F., C. Grano, L. Leone, C. Lombardo, and C. Pesce, 2004. "Determinants of The Intention to Use Doping Substances: An Empirical Contribution in a Sample of Italian Adolescents". International Journal of Sport Psychology, 35, 133-148.

Lucidi, F., A. Zelli, M. Luca, C. Grano, P. M. Russo, and C. Violani, 2008. "The Social Cognitive Mechanisms Regulating Adolescents' Use of Doping Substances". Journal of Sports Sciences, 26, 447-456.

Lundholm, L., K. Kall, S. Wallin, and I. Thiblin, 2010. "Use of Anabolic Androgenic Steroids in Substance Abusers Arrested for Crime". Drug and Alcohol Dependence, 111 (3), 222-226.

MacKinnon, D. P., L. Goldberg, G. N. Clarke, D. L. Elliot, J. W. Cheong, A. Lapin, E. L. Moe, and J. L. Krull, 2001. "Mediating 
Mechanisms in A Program to Reduce Intentions to Use Anabolic Steroids and Improve Exercise Self Efficacy and Dietary Behavior". Prevention Science, 2 (1), 15-27.

Manstead, A. S., R. C. Proffitt, and J. L. Smart, 1983. "Predicting and Understanding Mothers' Infant Feeding Intention and Behavior: Testing The Theory of Reasoned Action". Journal of Personality and Social Psychology, 44 (4), 657-671.

Mitic, P. and D. Radovanović, 2011. "The Motives for Doping Drug Use in Nonprofessional Athletes and Methods of Prevention". Physical Education and Sport, 9 (2), $203-212$.

Monaghan, L. F., 2002. "Vocabularies of Motive for Illicit Steroid Use among Bodybuilders". Social Science and Medicine, 55, 695-708

Montano, D. E. and D. Kasprzyk, 2008. "Theory of Reasoned Action Behavior, Theory of Planned Behavior, and The Integrated Behavioral Model" in: K. Glanz, B. K. Rimer and K. Viswanath, Health Behavior and Health Education: Theory, Research, and Practice" 67-92. $3^{\text {rd }}$ ed. San Francisco, CA: Jossey Bass.

Norman, R., 1975. "Affective Cognitive Consistency, Attitudes, Conformity, and Behavior". Journal of Personality and Social Psychology, 32, 83-91.

Nunnaly, J., 1978. Psychometric Theory. NY: Mcgraw Hill.

O'Keefe, D. J., 1990. Persuasion: Theory and Research. Newbury Park, CA: Sage.

O’Leary-Kelly, S. and R. Vokura, 1998. "The Empirical Assessment of Construct Validity". Journal of Operations Management, $16,387-405$

Park, S., 2000. "Relationships among Attitudes and Subjective Norms: Testing The Theory of Reasoned Action across Cultures". Journal of Communication Studies, 51 (2), 162175.

Pedhauzr, E. and L. Schmelkin, 1991. Measurement, Design, and Analysis: An Integrated Approach. NJ: Hillsdale.

Petroczi, A., 2007. "Attitudes and Doping: A Structural Equation Analysis of The Relationship between Athletes' Attitudes, Sport Orientation and Doping Behavior". Sub- stance Abuse Treatment, Prevention, and Policy, 2 (34), 1-15.

Petroczi, A., E. Aidman, and T. Nepusz, 2008. "Capturing Doping Attitudes by Self Report

Declarations and Implicit Assessment: A Methodology Study". Substance Abuse Treatment, Prevention, and Policy, 3 (9).

Poortinga, W., L. Stec, and C. Vlek, 2004. "Values, Environmental Concern, and Environmental Behavior". Environment and Behavior, 36 (1), 70-93.

Reno, R. R., R. B. Cialdini, and C. A. Kallgren, 1993. "The Transsituational Influence of Social Norms". Journal of Personality and Social Psychology, 64, 104-112.

Rokeach, M., 1973. The Nature of Human Values, New York: Free Press.

Rutter, D. and L. Quine, 2002. Changing Health Behavior. Buckingham: Open University Press.

Ryan, M. J., 1982. "Behavioral Intention Formation: The Interdependency of Attitudinal and Social Influence Variables". Journal of Consumer Research, 9 (3), 263-278.

Sagiv, L. and S. H. Schwartz, 2004. "Values, Intelligence and Client Behavior in Career Counseling: A Field Study". European Journal of Psychology of Education, 19 (3), 237-254.

Salisbury, W. D., W. W. Chin, A. Gopal, and P. R. Newsted, 2002. "Research Report: Better Theory through Measurement Developing A Scale to Capture Consensus on Appropiation". Information System Research, 13, 91103.

Schmidt, P., S. Bamberg, E. Davidov, J. Hermann, and S. H. Schwartz, 2007. "Die messug von Weternmit dem "Portrait Value Questionnaire". Zeitschrift für Sozialpsychologie, 38, 249-263.

Schifter, D. E. and I. Ajzen, 1985. "Intention, Perceived Control, and Weight Loss: An Application of The Theory of Planned Behavior". Journal of Personality and Social Psychology, 49 (3), 843-851.

Schwab, D., 1999. Research Methods for Organizational Studies. Mahwah, NJ: Lawrence Erlbaum Associates, Publishers.

Schwartz, S.H., 1994. "Are There Universal Aspects in The Structure and Contents of 
Human Values"? Journal of Social Issues, $50,19-45$.

Schwartz, S.H. and S. Huismans, 1995. "Value Priorities and Religiosity in Four Western Religions". Social Psychology Quarterly, 58, 88-107.

Schwartz, S. H., 1996. "Value Priorities and Behavior: Applying A Theory of Integrated Value Systems". The Psychology of Values, $8,1-24$.

Schwartz, S. H., 2007. Value Orientations: Measurement, Antecedents and Consequences across Nations, Measuring Attitudes Cross Nationally Lessons from The European Social Survey. London: Sage Publications.

Schwartz, S. H., and A. Bardi, 2001. "Value Hierarchies Across Cultures: Taking a Similarities Perspective". Journal of Cross Cultural Psychology, 32, 268-290.

Sheppard, B. H., J. Hartwick, and P. R. Warshaw, 1988. "The Theory of Reasoned Action: A Meta-Analysis of Past Research with Recommendations for Modifications and Future Research". The Journal of Consumer Research, 15 (3), 325-343.

Sheth, J. N., B. I. Newman, and B. L. Gross, 1991. "Why We Buy What We Buy: A Theory of Consumption Values". Journal of Business Research, 22, 159-170.

Shimp, T. A. and A. Kavas, 1984. "The Theory of Reasoned Action Applied to Coupon Usage". Journal of Consumer Research, 11 (3), 795-809.

Simon, P., H. Striegel, F. Aust, K. Dietz, and R. Ulrich, 2006. "Doping in Fitness Sports: Estimated Number of Unreported Cases and Individual Probability of Doping. Addiction, 101, 1640-1644.

Skarberg, K., F. Nyberg, and I. Engstrom, 2009. "Multisubstance Use as A Feature of Addiction to Anabolic Androgenic Steroids". European Accident Research, 15, 99-106.

Strelan, P. and R. J. Boeckmann, 2003. “A New Model for Understanding PerformanceEnhancing Drug Use by Elite Athletes".
Journal of Applied Sports Psychology, 15, 176-183.

Tahtamouni, L. H., N. H. Mustafa, A. A. Alfaouri, I. M. Hassan, M. Y. Abdalla, and S. R. Yasin, 2008. "Prevalence and Risk Factors for Anabolic Androgenic Steroid Abuse among Jordanian Collegiate Students and Athletes". European Journal of Public Health, 18 (6), 661-665.

Titah, R. and H. Barki, 2009. "Nonlinearities between Attitude and Subjective Norms in Information Technology Acceptance: A Negative Synergy"? MIS Quarterly, 33 (4), 827-844.

Vallerand, R. J., P. Deshaies, J. P. Cuerrier, L. G. Pelletier, and C. Mongeau, 1992. "Ajzen and Fishbein's Theory of Reasoned Action as Applied to Moral Behavior: A Confirmatory Analysis". Journal of Personality and Social Psychology, 62 (1), 98-109.

Vaske, J.J. and M. P. Donnelly, 1999. "A Value Attitude Behavior Model Predicting Wildland Preservation Voting Intentions". Society and Natural Resources, 12, 523537.

Warshaw, P. R., 1980. "A New Model for Predicting Behavioral Intentions: An Alternative to Fishbein". Journal of Marketing Research, 17 (2), 153-172.

Wiefferink, C.H., S. B. Detmar, B. Coumans, T. Vogels, and T. G. W. Paulussen, 2008. "Social Psychological Determinants of The Use of Performance Enhancing Drugs by Gym Users". Health Education Research, $23,70-80$.

Wicker, A. W., 1969. “Attitude Versus Action: The Relationship of Verbal and Overt Behavioral Responses to Attitude Objects". Journal of Social Issues, 25, 41-78.

Ybema, S., D. Yanow, H. Wels, and F. Kamsteeg, 2009. "Studying Everyday Organizational Life", in: S. Ybema et al. ed. Organizational Ethnography. London: Sage.

Zuckerman, M. and H. T. Reis, 1978. "Comparison of Three Models for Predicting Altruistic Behavior". Journal of Personality and Social Psychology, 36 (5), 498-510. 